\title{
New Religious Authority of Islamic Millennial: A Study of Rohis Community in Medan City
}

\author{
S T Sumanti \\ University of State Islamic North Sumatra Medan \\ \{solihahtitinsumanti@uinsu.ac.id\}
}

\begin{abstract}
Teenagers, or today mostly known as millennial generation, is transition phase from the child to the adult category. They look for identity through various activities such as Rohis community. This research focuses on how Rohis community of Madrasah Aliyah Negeri (MAN) in Medan city determines religious authority. The study also discusses how this spiritual community organized the group, built the network strategy, strengthened solidarity, and constructed an Islamic identity. The object of research is Muslim millennial generations who are member of Rohis of Madrasah Aliyah Negeri. Medan is one of the biggest city with large of population of millennial Islam as representation of Indonesia and Rohis is a powerful and influential religious of teenagers. Qualitative method is by interview, observation and group discussion. This study results in a fact that this group does not follow the conventional religious authority but populism. The culture of populism with gadget as part of the life-style including social media applications has constructed the spiritual identity especially in choosing and sorting out religious teachings to practice. The religious authority shifted form conventional to a new determining power, such as to determine patterns, shapes, styles and ways of practicing Islamic teachings. Their religiosity suggests symbolic identities, such as dressing, religious rituals and Islamic jargon can recognize among teenagers in the public sphere. Referring to the revealed they can be identified as groups inclined to the "culture of Wahabism". Culture "New Wahabism" is appearing in a new form in strengthening the network of "da'wah" through social media.
\end{abstract}

Keywords: Religious Authority, Rohis, Millenial

\section{Introduction}

The phenomenon of Islamic spirituality was not only limited to political movements and propaganda in schools, but this phenomenon was apparently closely related to "moral panics" (moral panic) in Indonesia, especially after Western and East Asian pop culture has rapidly developed. As a result, pop culture that penetrated Indonesia since the 1970s has in fact caused a reaction with the emergence of counter-pop culture that came from among Muslims. Concerns about the "ghost" of pop culture among teenagers were "fended off" with the intensification of Islamic da'wah among students, so that the campus preaching bags called Rohis stood up. It was this moral panic that made the school or Rohis missionary movement popular among Indonesian Muslim youth[1]. 
In his study, Kailani revealed that the current Rohis phenomenon in Indonesia is closely related to the dynamics of the Islamic movement in the New Order and Reformation. He pointed out that the restrictive situation of political Islam on the one hand and the space for the expression of piety in the New Order on the other hand had made the Islamic movement into its maturity in the Reformation era. Many spiritual groups are affiliated with certain political movements. The result is as visible in recent researches such as the Wahid Institute and others.

In the past decade or so, the activities of Islamic Spirituality (Rohis) in schools have been widely discussed by social scientists, especially since the movements of Islamism have become increasingly massive in their existence. Rohis is often reported in the media because it is suspected to be a seedbed for radicalism understanding from radical groups which infiltrate Rohis activities in schools. Rohis is ideally a place for Muslim students to develop their knowledge and insights about Islam through various activities.

A study by the Institute for Islamic Studies and Peace (LaKIP) in 2010 found that there is a tendency towards radicalism among high school students, even though only a small proportion of Rohis activists were students who were radically inclined[2]. As is generally known that the Rohis extracurricular activities always exist in schools and indeed must be admitted very much in demand. Students who choose to join Rohis at their school usually have full support from their parents. Parents believe that Rohis' activities help to improve their children's knowledge of Islam.

The research was undertaken by Religious and Cross-Cultural Studies Program UGM also resulted that existence of Rohis in schools is influenced by several factors, including in adequate learning methods and facilities in schools, so that Islamic religious learning in schools is less attractive, textual, monotonous, boring, only lectured, and very exclusive. The direction of religious learning is commonly dogmatic[2].

Along with the development of the age and information technology today, the use of devices becomes the main needs of the community. Gadgets (gadgets) are used by almost all groups, except for the elders because it makes them difficult to follow, because it is not a toy. But toddlers are now being introduced by some parents who mistakenly assume it can replace conventional toys. It is not uncommon to find cases of toddlers whose eyes have become near sight endue to excessive use of devices and not under the supervision of their parents. The most massive device isused by millennials or adolescents born in the 2000. Millennials are now entering the early transition from adolescence to early adulthood. At this time parental supervisi-on is much reduced, home range is expanding, friendship is increasing, life is full of adventure and experimental, and of course more adept at imitating.

Many people think that millennial is the most easily influenced group. What was done when those times greatly influenced the formation of his identity in the future. This is where the need for good moral and religious education. Smartphones and social media are two things that are very familiar in millennial life, especially in urban areas. Now with all the conveniences, it is almost impossible to find teenagers from urban millennials who do not have smartphones and do not use social media. Social media is the most used tool through which most millenials access information.

Besides having an entertaining element, social media has also many useful features. Information is no longer monopolized by conventional mass media. Today information is very open and can be easily disseminated through a process known as citizen journalism. Expansion of information through citizen journalism takes many forms and variations with different objectives and benefits. Social media or other types of new media based on internet technology (new media) are used by all people from different back ground sand interests, religion, organizations, communities, business people, celebrities, educators, and others. This 
article focuses on Rohis activists who are identified as millennial in order to find out the extent of the shift in religious authority among millennial Muslims from the massive use of social media.

\section{Method}

By using qualitative method, data is collected through interviews, observations and group discussions. Other data were obtained mainly from literature studies such as scientific articles from several national journals. This research was conducted in early 2019 in Medan City. Its location is specifically directed to several schools such as Madrasah, represented by MAN 1 Medan and MAN 2 Model Medan, and public schools from SMA 3 Medan, SMA TRITEK Medan, SMK Negeri 1 Medan. The data was retrieved from focus group discussions gradually in one place. The list of questions asked in an unstructured way is adjusted to the responses and answers during the discussion. This study also uses a depth interview with Islamic religious teachers and Rohis members, either personally or individually. The questions of intervewer do not directly lead to the core of the data to be extracted, but rather in a subtle way so that the informant is comfortable and the data is presented as it is without suspicion.

\section{Result and Discussion}

\section{Rohis in Islamic Studies Discourse in Indonesia}

Rohis is an Islamic da'wah organization among students in a school environment. Usually under the Intra-School Student Organization (OSIS), Rohis is an institution to strengthen Islam. Rohis's real function is forum, mentoring, propaganda, and sharing. Rohis generally has separate activities between male and female members due to differences in muhrim between members. Togetherness can also be established between members with meeting activities and outdoor activities. The main goal of Rohis is to educate students to become more Islamic and to be well acquainted with the Islamic world. In practice, members of the Rohis have advantages in delivering religious 'propganda' to know God more closely. Rohis always draws members closer to Allah SWT, and keeps members from terrorism, error, and so on[3].

Rohis is clearly an instrument of Islamic education that exists in almost all schools in Indonesia. In fact, not only as an educational instrument, Rohis was also known as an organization of religious movements. Religious movements in this context are understood within the general framework used by social scientists, namely a movement that deals with spiritual issues or supernatural things that oppose or propose alternatives to some aspects of religion or the dominant cultural order. Religious movements in certain local contexts tend to position a spectrum of thought as the legitimacy of the movement. Community members design key agenda as around fundamental issues concerning the meaning of life and Islamist practices should permeate everyday elements of society. There is a desire to preserve the essence of collective identity which is indeed formed from a common vision. Their strong collective identity shapes their solid solidarity with various informal facilities, especially campuses, schools, and mosques[2].

Rohis also has a social religious attitude. This kind of student religious movement is based on a vision that a movement does not only refer to a large entity, but a;sp refer to a small local entity. Rohis began to appear around the early 80 s which indeed gave a new tendency to the direction of the Islamic activism movement among students. School institutions are an effective means for the dissemination of religious understanding and a means of disseminating certain Islamic ideologies. The ideology in question is a group of Islamic revivalism 
movements. Rohis has changed the orientation of his movement of a small entity from the school system to a larger entity which eventually crystallized into social religious attitude of Rohis at school[2].

The existence of Rohis in various schools is disturbed by the existence of public opinion that radical Islamic movement is driven by many young people. Religious radicalism that leads to violence often quickly spreads its influence among teenagers in schools. Rohis was suspected to be a vehicle for recruiting radical groups. Initially, Rohis as a cultural and ceremonial activity to help organize Islamic holidays in schools, but its development since the 1990s gradually transformed into religious organizations that tend to be ideological thought and movement. The strength of ideology can be seen in terms of attitudes of activists who tend to be exclusive, excluding any idea of pluralism. This movement always continuously strengthen in line with development of the Tarbiyah movement in schools.

Ciciek Farha (2008) as quoted in the CRCS of Gadjah Mada University religious life report found that Rohis tends to develop exclusive views and attitudes, which are a reflection of certain Islamic groups so that they successfully attract students to the attitude of 'radicalism' of religion[3].

Najib Kailani found that Rohis was a phenomenon which was apparently not only limited to political movements and propaganda in schools, but was closely related to "moral panics" (moral panic) in Indonesian society especially after Western pop culture and East Asia began to develop. In his research in Yogyakarta between 2008-2009, Kailani turned out that pop culture which had penetrated Indonesia since the 1970s had caused a reaction with emergence of counter-pop culture among Muslims represented by activists of the Campus Propagation Institute and publication of magazines for Muslim youth. One of the most famous is Annida magazine. Besides through magazines, propaganda activists also expand their activities to schools, especially through Rohis. Rohis, which was previously characterized as being more inclusive for all students, has increasingly become exclusive to Muslims by carrying on the traits of his carrier[1].

\section{Islamic Activism: Movements, Networks, and Symbolic Identity Struggles}

The entry of various Islamic movements in high schools has been going on since the 1980s when the movement gained momentum in expanding their ideology on various fronts. The momentum of ideological expansion is suspected as a culmination point of the community who are trying to find alternative new public spaces in the practice of learning and practicing Islam. In the midst of the New Order regime in controlling politics and Islamic activities in each mosque, Islamic movement was informally able to make spiritual field contained in various educational and social institutions as a public space for new Islamic activities that were spared from the regime's control, and Rohis was no exception[4],[5].

The various variants of the Islamic movement in holding the Rohis have strenghthened their identities towards a particular Islamic movement. The strengthening of identity is not only limited to the existence of ideological and symbolic differentiation between various Rohis institutions in interpreting "Islam and non-Islam" and the instruments contained such as: Islamic dress codes, relations between men and women, relationship between Islamic education and formal education, but also differentiation in understanding the state, citizenship, and democracy.

The various Islamic movements outside the school environment attempt to sharpen their ideological influence on the institution by carrying out hegemony or political spirituality with various expressions and orientations. Various Islamic movements try to utilize public space to actualize the project of re-Islamization through preaching activities both for individuals and 
institutions. The re-Islamization project is plural and has its own characteristics both compromising, such as: Islamist, populist, moderate, and religious nationalists, and noncompromising, such as revivalists and radical. The different characteristics of the Islamic movement strive to sharpen the influence of the Rohis on public space both by: (1) various ideological and cultural symbols, such as: religious learning curricula, associations of extraschool student associations, construction of ways of dress, to communication culture which exists both internally and externally on Rohis institution; (2) differences in interpreting the "teachings of Islam" between various Islamic movements have provided opportunities for every elite of the Islamic movement to create barriers and make the issue of differentiation an argument for strengthening identity among them. Islamic movement elites often used this situation to legalize certain political-economic interests.

Social media is indeed a very effective means to show the existence and increase the influence of an entity. Now a days, almost everyone, especially in urban areas, has become dependent on smartphones and social media. Similar to what is done by business people, social media is a means that has the greatest opportunity to promote something to the audience. Rohis and its community members were greatly helped by a presence of social media in addition to obtaining information but also strengthening solidarity. Rohis utilizes technology and social media to expand its network and influence especially with the aim of enlarging influence among Muslim millenials outside Rohis and strengthening networks of fellow Rohis activists from elsewhere.

In demonstrating its existence, many Rohis groups are preaching and spreading its influence through accounts on well-known social media. The uploaded content is not far from moral messages, quotes, aphorisms, religious messages, lecture excerpts, information on preaching activities and others that follow trends in social media. All contents are sought to be impressive and Islamic. This will affect public image of Rohis through social media. It really depends on how a group of Rohis activists will make its public image certainly different. Moreover, millennials are very open and tolerant to diversity. It would be unfair if Rohis's identities were to be uniformed. The most strengthening of Islamic identity in Rohis can utilize the symbols of Islam, obedience, holiness, and divinity inherent in the content on social media. As long as it continues to circulate on social media, so long as the strengthening of identity continues in a pseudo-movement. This is the reason of the ways the new media has an extraordinary influence in the 21 st century.

\section{New Religious Authority of Islamic Millennial}

Islamic religious authority is to carry out and order rules that are considered according to God's will. The idea of authority is certainly very problematic because of the assumption that the sole authority is the God Almighty. In Islam, religious authority is belonging to those who have the ability to invite and direct to the teachings of Islam. Traditionally the religious authority is in the hands of the ulama or kyai or cleric. They become interpreters of Islamic arguments needed by the people especially fatwas. They also function as educators of Islamic teachings and in still Islamic values in the community.

Kramer and Schimdtke interpret that religious authority and power are not always easy to distinguish[6]. Religious authority can be assumed in several forms and functions: ability (opportunity, strength, or right) to determine true beliefs and practices, or orthodoxy and orthopraxy, respectively; to shape and influence views and do according to certain desires, to identify, marginalize, punish deviations, heresy and heresy of followers of a teaching. In monotheistic religions based on the revealed scriptures, religious authority involves more power (opportunity, strength, or rights) to compile and determine the "authoritative" canon of 
texts and legal methods of interpretation. The difference between authority and power is blurred. Authority is closely related to the idea of legitimacy/power. In the same way, this is related to the concept of trust. Religious authorities can come from individuals, groups of people, or institutions[7].

Kuntowijoyo describes dynamics of religious sensitivity that do not always involve conventional symbols that have existed before, such as mosques, madrassas, boarding schools, and places where people get Islamic messages from teachers, religious teachers, clerics, and preachers. The idiom also presupposes a new sketch that illustrates the increasingly broad religious space that is marked by an increase of religious interest and passion among Muslims as a result of the increasing number of sources of new religious authority outside the sources of traditional authority[8].

The rapid development of information technology affects all aspects of human life, both individually and socially. It can be seen in the fields of community activities such as social, political, economic, cultural, and even religious. Changes occur in religious aspects such as thoughts, fatwas, religious practices, and relationships that are interwoven with religious norms. Teusner and Cambell argued that this trend is both a challenge and a hope for religions when the use of modern technology, called "new media", has opened the space for new ideas to emerge and be influential globally.

However, now the religious authority is shifting to new, seemingly impersonal, media that are based primarily on information networks (internet). Everyone can easily access knowledge according to their individual tastes and needs. A person who needs an answer to a problem does not have to ask ulama directly. Religious facts no longer only belong to conventional ulama. Now, anyone can find answers and make decisions based on information available in the media[8].

In recent years, recent studies of the Islamic public have emphasized the importance of new media in shaping and influencing Muslim behavior in the public sphere. Mainly about how the process of democratization and public fragmentation has taken place as a result of the capacity of new media which weakens the dominance that has been established, such as the state and ulama institutions. Conclusion Dale F. Eickelman, for example, states that the emergence of a new class of "Islamic activists" throughout the Muslim world has gone hand in hand with the spread of new information technology, such as cassettes, audio CDs, satellite television, and the internet. This is a new discourse on how Muslims present themselves with their identities in a society that is constantly changing. The new media, by its aggressive nature, creates new structures and arrangements so that the fundamental impact of changing established patterns in people's lives goes beyond its limits, and enables the disarming of traditional religious authority[8].

For Muslims, the issue of religious authority is not simple, both in terminological definition and its implementation, in the experience of religious life. It is no exaggeration to say that Indonesia is the most difficult Muslim country to answer the question of who is the sole owner of a religious authority that has a authority to regulate and give direction to Muslims to translate the messages of Islam in life. In a new media-based society as explained earlier, society is increasingly dispersed both socially and intellectually as it is today. It is almost unable to determine who owns religious authority and what its limits. In other Muslim countries, this problem can be answered by pointing the finger at the state government or the appointed and elected fatwa institution such as in Malaysia, Brunei, or in the Middle East[8].

However, it should be noted, in modern times, a balanced relation between religious and political authority has shifted radically. State vis-à-vis ulama has crossed far in ways unimaginable two centuries ago in Indonesia. The Indonesian nation state does not embrace 
these two models. Indonesia is not an Islamic country, even though its population is 88.7 percent Muslim. Islam is also not an official state religion because Indonesia does not have an official religion. Indonesia only recognizes a number of religions, i.e. Islam, Christianity, Catholicism, Hinduism, Buddhism, and Confucianism. Therefore, Islam as well as other religions are in the hands of their own people. Indonesia does have a Ministry of Religion (formerly the Department of Religion) since the first cabinet after independence, but it does not become an Islamic authority. Moreover, this ministry is not specifically concerned with the affairs of the Islamic community, but also other religious communities. It is thus understandable why the authority of Indonesian Islamic religion became scattered and continued to multiply in more recent times when various factors influenced religious authority[8].

Along with the development of new media information technology accompanied by the traditional authority, the religious authority is shifting to impersonal media, such as books, websites, blogs, and the like. Books viewed from the material derived from paper can indeed be categorized as conventional media. However, the book industry cannot be called conventional media anymore because such industry is also based on new media and Internet. Nowadays anyone can learn Islam from books and internet available in various places. The Muslim generation now seems to be quite proficient in Islamic science even though they have never received formal education in madrasah or Islamic boarding schools. They study Islam without being mentored by scholars or clerics. This means that the Muslim generation is now learning Islam from new sources that are different from traditional sources of prior knowledge[8].

Among young people, students, and students, now more prioritizing browsing the internet than asking the cleric directly or reading a book in the library in search of answers to religious problems. Debbie Herring figures out that internet and new media would make the new religious authority only a moderator of an online group that was identified and treated as a legitimate spiritual authority by members of the religious community online[9]. The new media not only increases access to alternative sources of religious information, but also empowers people to contribute information, opinions, and experiences for enrichment of public discourse and dialogue. This means Muslims must develop new skills in technology literacy. They also need new skills from affirmation to see how new media has created a new social environment that facilitates spiritual interaction, creates new authority, and legitimizes action in religious communities.

Adolescents or those who are represented as the generation of birth in the $2000 \mathrm{~s}$ (millennial generation) are the most important people to use social networks based on internet networks. In Medan, for example, religious authority among millennials shows a tendency towards new media. This is evident from the pattern of activities undertaken by Rohis MAN 2 Model Medan activists who are very intensely propagating propaganda content on social media referring to cleric Abdul Somad, Adi Hidayat, and Hannan Attaki. These names are very popular these days as a lecturer. They have their bussines channel on YouTube and have a social media account with a incredible number of followers. Likewise, Rohis MAN 1 Medan activist also has the same tendency.

Based on observations and monitoring on well-known social media that are most widely used in Indonesia: Facebook, Instagram, Twitter and WhatsApp, it is undeniable that online lecturer that refers to popular lecturers has lately become a trend in the social media cycle. Content created, uploaded, distributed, accessed, watched, downloaded, and re-uploaded by citizens is in the form of meaningful quotes, video clips of lectures, missionary activities, and so on following the citizens' creativity and the development of social media features. The 
outstanding content becomes public property which is freely distributed without limitation by anyone and at any time. In fact, there are times when Islamist content is dragged into political interests and propaganda of certain groups, even at such times the intensity and speed of circulation of such content increases dramatically. This phenomenon is well known as "viral". The number one video player website in the world, YouTube, is one of the main and most massive accesses used to make things go viral on the internet.

The influence of the ease of features available on social media seemingly accelerates the spread of popular propaganda content among millennials and even spreads easily to the general public. Not only that, Indonesian people are also sharing interesting content to others by broadcasting. Although the content is circulating freely, rather than ordinary millennials, Rohis activists are more critical in terms of consuming information. They exclusively conduct discussions and dissect information from interesting content that they find both on social media websites and conventional books.

Based on the results of discussions with activists Rohis MAN 1 Medan, it was concluded that ideologically it did not show an anti-Pancasila tendency. Some believe that the ideology of Pancasila is absolutely guided by all citizens. Others assert their beliefs by linking Pancasila with the pillars of faith. However, some Rohis activists look more critically at Pancasila in the context of their views on the situation observed in life. Simply put, they view that Pancasila is the right ideology, but there are still many citizens who do not practice it perfectly.

In addition, millennials are more tolerant of religious life. Even though the Rohis activists in MAN 1 Medan and MAN 2 Medan Model often access Islamic websites and content on social media, they are very tolerant of non-Islamic content that is circulating and accessed by people around them. They as citizensup hold diversity. Millennials are more open (open minded) to the development of the world in addition to being very consumptive to the development of gadgetry (gadget) technology. But compared to it spredecess or generations, millennials are some what Islamist-Pancasilais-Pluralist. The shift of religious authority among millennials in particular the Rohis activists in Medan to new media turned out to follow a general pattern.

New media is a cross-age requirement, its sources cannot be limited by a person's age. From the writer's observation it can be concluded that in fact there began tobe a shift in religious authority among parents from millennial. This is because middle-aged parents are familiar with technology and social media as well as bridging the millennial generation with the older generation. Millennial parents have an active tendency to access social media and spread Islamist content as practiced by millennials. Thus the shift of religious authority in millennials cannot be said to be a surprise either. This is a predictable change. So far, even though there has been a shift in religious authority among millennials, in terms of nationalism as an Indonesian citizen, they still show their belief in Pancasila as an ideology of the state that must be followed.

Rohis in public schools have different characteristics with Rohis in Madrasah schools. Although in general there are no striking differences. The difference lies in the process of accessing religious information obtained by Rohis in public schools. Most of the religious activists have public school back grounds, while those in Madrasah have religious school back grounds. this in the process of reception and interpretation of Islamic teachings has differences. How to analyse and understand the values gained from the mentoring process for religious activists in public schools tend to be rigid and not have a variety of religious information. The mentors are the same, most of them lecture on public campuses where there are not many religious studies either. In addition, very few alumni who became mentors were found with the boarding school education background. 
Rohis' choice to religious authority in public schools tends to lead to the model of populist religious figures, namely religious figures who are popular for the network of spiritual movements. It is not uncommon for popular religious figures to propagate through social media channels such as Hanan Attaki, Ustadz Basalamah, Zakir Naik are his choices. Meanwhile, among the Rohis who come from Madrasah, they have different variants, although at the same point they idolize the same figure at the level of religious authority active in social media, but at the same time they also place religious authority on religious figures which is not popular on social media, such as religious institutions Alwashliyah, NU, Muhammadiyah and the Indonesian Ulema Council.

Therefore, the author does not dare to analyze the religious construction of the spiritual because there are fundamental differences in the way of religious view among spiritual activities. This certainly must be a concern among academics who study the Rohis as part of religious movements in educational institutions. Because it must precisely position the spiritualists in the context of the background of how they access and then manage the religious values received from various sources.

\section{Conclusion}

Religious authorities can apparently transform in line with support of new internet-based media. Millennial is the most massive use of social media and at the same time vulnerable to its influence. Millennial religious authority has shifted to no longer follow the clerics and clerics as conventional religious authorities, but rather lead to populism represented by social media content referring to popular speakers in millennials. This massive culture of using gadgets and social media shapes the millennial spiritual identity formed by the teachings that are practiced from what it chooses. In terms of the formation of the Islamic identity of this group through clothes, life styles, rituals, and distinctive jargon, the dominant Wahhabism influences brought by their carriers began to beeroded by new influences. This new identity can be called the New Wahhabism. Islam in Indonesia has given birth to a new face of inseprable strong appeal of technology.

\section{References}

[1] N. Kailani, "Kepanikan Moral dan Dakwah Islam Populer (Membaca Fenomena 'Rohis' di Indonesia,” Anal. J. Stud. Keislam., vol. 11, no. 1, pp. 1-16, 2011.

[2] A. Habibullah, "Sikap Sosial Keagamaan Rohis di SMA Pada Delapan Kota di Indonesia," EDUKASI J. Penelit. Pendidik. Agama dan Keagamaan, vol. 12, no. 3, Dec. 2014.

[3] Z. Yani, "Bacaan Keagamaan Aktivis Rohis: Studi Kasus di SMA Negeri 3 dan 4 Kota Medan," Penamas, vol. 27, no. 1, pp. 47-62, 2017.

[4] M. Shidiq, KAMMI dan Pergulatan Reformasi: Kiprah Politik Aktivis Dakwah Kampus dalam Perjuangan Demokratisasi di Tengah Gelombang Krisis Nasional Multidimensi. Solo: Era Intermedia, 2003.

[5] E. Aspinall, Opposing Suharto: Compromise, Resistance, Regime Change in Indonesia. California: Stanford University Press, 2005.

[6] G. Kramer and S. Schmidtke, Speaking for Islam: Religious Authorities in Muslim Societies. Leiden: Brill, 2006.

[7] Zulkifli, "The Ulama, Religious Authority and Recognition in Indonesia," in Kumpulan Makalah ACIS X, 2010. 
[8] M. Jinan, "New Media dan Pergeseran Otoritas Keagamaan Islam di Indonesia," $J$. Lekt. Keagamaan, vol. 10, no. 1, pp. 181-208, 2012.

[9] D. Herring, "Virtual as Contextual: A Net News Theology," in Religion and Cyberspace, M. T. Hojsgaard and M. Warburg, Eds. New York: Routledge, 2005, pp. 149-165. 